Volume I Tahun 2021

November 2021
E-ISSN: 2808-5361

http://e-journal.fkmumj.ac.id/
Proceeding The First

Muhammadiyah Internasional-

Public Health and Medicine

Conference

\title{
Description of Smoking Behavior in Adolescents ages 15-18 Years
}

\section{${ }^{1}$ Ade Gustiawan, ${ }^{2}$ Adi Rizfal Efriadi, ${ }^{3}$ Alief Jordan, ${ }^{4}$ Arbian Humaidi, ${ }^{5}$ Dandi Surya}

Faculty of Public Health, Muhammadiyah University of Jakarta

K.H. Ahmad Dahlan St, Cireundeu, Ciputat, South Tangerang, 15419

Email: arbianhumaidi18@gmail.com

\begin{abstract}
Smoking is a problem that has not been solved until now. Smoking has spread to various groups, from children to the elderly, men and women. This smoking habit can harm adolescents directly or indirectly which has been proven to interfere with the growth and development of adolescents. Many factors are associated with smoking behavior in adolescents aged 15-18 years. These factors are discussed based on research articles and book references. Factors that influence the relationship include peer association, price, and lack of parental attention. Smoking can increase the risk of several diseases, such as cancer, pregnancy disorders, and hypertension. Smoking too often not only causes problems in the development and growth of adolescents.
\end{abstract}

Keywords: Adolescents, Smoking Behavior, Cigarettes 
E-ISSN: 2808-5361 http://e-journal.fkmumj.ac.id/
Proceeding The First Muhammadiyah InternasionalPublic Health and Medicine

Conference

\section{INTRODUCTION}

Smoking is a problem that has not been solved until now. Smoking has spread to various groups, from children to the elderly, men and women.

Adolescents are people who are between the ages of 10 and 19 years. According to the Regulation of the Minister of Health Number 25 of 2014, adolescents are the age group of 10 years to 18 years. Adolescence begins at age 12 and ends around age 17 or 1829. Adolescents have special nutritional needs compared to other age groups. This is because at the time of adolescence there is rapid growth and changes in physiological maturity in connection with puberty.

Cigarettes are one of the addictive substances which, when used, pose a danger to the health of individuals and society. Then some define that cigarettes are processed products of wrapped tobacco including cigars or other materials produced from the Nicotinia Tabacium plant. Nicotinia Rustica and other species or their synthesis containing nicotine and tar with or without additives.

At present, many teenagers have dared to smoke cigarettes. Adolescents with smoking behavior are currently considered normal behavior in society, the current highest prevalence of smoking also occurs in adolescents. Smoking behavior is a lifestyle that is detrimental to the health of oneself and others.

Various negative effects caused by cigarettes, directly and indirectly, have been proven to interfere with the development and growth of adolescents. According to medical science, cigarettes contain approximately 4000 chemicals, tar, carbon monoxide, and hydrogen cyanide, nicotine found naturally in cigarette stems and tobacco leaves which contain the highest nicotine as much as $5 \%$ of the weight of tobacco.

Seeing the various negative effects caused by cigarettes that have been described previously, it will be discussed in more depth what factors are related to smoking behavior in children. In addition, it will also discuss the health effects of smoking on adolescents.

\section{METHODS}

This study uses a quantitative research method with a cross-sectional study design where the measurement of variables is carried out at a certain time. The data collected in this study were the characteristics of the respondents, knowledge about smoking, smoking behavior, and peer influence. The variables in this study include independent variables such as knowledge about cigarettes, smoking behavior, and peers. The dependent variable is cigarette consumption. The data were obtained from the results of the knowledge questionnaire interview, smoking behavior, and the influence of semiquantitative FFD peers. 
E-ISSN: 2808-5361 http://e-journal.fkmumj.ac.id/
Proceeding The First Muhammadiyah InternasionalPublic Health and Medicine

Conference

\section{RESULTS AND DISCUSSION}

\section{Table 1. Fast Food Interview Matrix in Youth from Informant 1}

Name: Rizki Rahmat

Age/TTL :18 Years (3 High School)

Place of Interview: Rizki's house

Interview Time : May 28, 2021

\begin{tabular}{|c|c|c|c|}
\hline & QUESTION & INFORMATION ANSWER & ANSWER CONCLUSION \\
\hline 1 & $\begin{array}{l}\text { Please tell me how long have } \\
\text { you been smoking? }\end{array}$ & $\begin{array}{l}\text { Started smoking from the } 2 \text { nd } \\
\text { grade of high school }\end{array}$ & Over 17 years old \\
\hline 2 & $\begin{array}{l}\text { How did you first taste } \\
\text { cigarettes? }\end{array}$ & Feel Calm & Quiet \\
\hline 3 & $\begin{array}{l}\text { Do your parents know you have } \\
\text { smoked? }\end{array}$ & Don't know until now & Do not know \\
\hline 4 & Is there a reason you smoke? & Following hangout friends & Prestige if you don't smoke \\
\hline 5 & $\begin{array}{l}\text { And tell me how did you get to } \\
\text { smoke? }\end{array}$ & $\begin{array}{l}\text { Just try it at the beginning to } \\
\text { follow friends hanging out }\end{array}$ & Just try then get addicted \\
\hline 6 & $\begin{array}{l}\text { At what age did you first } \\
\text { smoke? }\end{array}$ & 18 years & 18 years \\
\hline 7 & $\begin{array}{l}\text { How many cigarettes a day } \\
\text { smoke }\end{array}$ & 1 Pack & 12 cigarettes \\
\hline 8 & $\begin{array}{l}\text { Do you feel like quitting } \\
\text { smoking? }\end{array}$ & It's just hard to quit smoking & Active smoker \\
\hline 9 & $\begin{array}{l}\text { Do you feel restless if you don't } \\
\text { smoke? Or dizzy? }\end{array}$ & Feeling dizzy if you don't smoke & Daily needs \\
\hline 10 & $\begin{array}{l}\text { What kind of cigarettes do you } \\
\text { smoke }\end{array}$ & Warehouse Salt Filter & Warehouse Salt Filter \\
\hline
\end{tabular}

Table 2. Fast Food Interview Matrix in Youth from Informant 2

Name: Imam F

Age/TTL :16 Years (1 High School)

Place of Interview: Street

Interview Time : 30 May 2021

\begin{tabular}{clll}
\hline \multicolumn{1}{c}{ QUESTION } & \multicolumn{1}{c}{ INFORMATION ANSWER } & ANSWER CONCLUSION \\
\hline 1 & $\begin{array}{l}\text { Please tell me how long have } \\
\text { you been smoking? }\end{array}$ & Since the age of 15 years & under 17 years old \\
\hline 2 & $\begin{array}{l}\text { How did you first taste } \\
\text { cigarettes? }\end{array}$ & $\begin{array}{l}\text { When you start smoking, you } \\
\text { immediately cough, there's just a } \\
\text { feeling of addiction }\end{array}$ & Cough and addiction \\
\hline 3 & $\begin{array}{l}\text { Do your parents know you have } \\
\text { smoked? }\end{array}$ & Of course not & Do not know \\
\hline 4 & Is there a reason you smoke? & $\begin{array}{l}\text { At first, I just tried to keep getting } \\
\text { addicted }\end{array}$ & Curious \\
\hline 5 & $\begin{array}{l}\text { And tell me how did you get to } \\
\text { smoke? }\end{array}$ & $\begin{array}{l}\text { Because the association joins } \\
\text { friends on smoking }\end{array}$ & Friends influence \\
\hline 6 & At what age did you first & 15 years & 15 years \\
\hline
\end{tabular}


E-ISSN: 2808-5361 http://e-journal.fkmumj.ac.id/
Proceeding The First Muhammadiyah InternasionalPublic Health and Medicine

Conference

\begin{tabular}{clll}
\hline \multicolumn{1}{c}{ QUESTION } & INFORMATION ANSWER & ANSWER CONCLUSION \\
\hline & smoke? & About 3-8 sticks per day & 3-8 sticks per day \\
\hline 7 & $\begin{array}{l}\text { How many cigarettes a day } \\
\text { smoke }\end{array}$ & $\begin{array}{l}\text { So far there is no desire to quit } \\
\text { smoking }\end{array}$ & Nothing \\
\hline 8 & $\begin{array}{l}\text { Do you feel like quitting } \\
\text { smoking? }\end{array}$ & $\begin{array}{l}\text { Lo, just lacking confidence } \\
\text { smoke? Or Or dizzy? }\end{array}$ & Mack of confidence \\
\hline 9 & $\begin{array}{l}\text { What kind of cigarettes do you } \\
\text { smoke }\end{array}$ & Magnum Blue & Magnum Blue \\
\hline
\end{tabular}

Table 3. Fast Food Interview Matrix in Youth from Informant 3

Name : Muhammad Azmi Haikal

Age/TTL: 18 years (3 high schools)

Place of Interview: Food Stall

Interview Time : June 1, 2021

\begin{tabular}{clll}
\hline No & \multicolumn{1}{c}{ QUESTION } & \multicolumn{1}{c}{ INFORMATION ANSWER } & \multicolumn{1}{c}{ ANSWER CONCLUSION } \\
\hline 1 & $\begin{array}{l}\text { Please tell me how long have } \\
\text { you been smoking? }\end{array}$ & It's been 2 years since 2019 & Under 17 years old \\
\hline 2 & $\begin{array}{l}\text { How did you first taste } \\
\text { cigarettes? }\end{array}$ & $\begin{array}{l}\text { The first time, at first, try and get } \\
\text { addicted }\end{array}$ & At first, dabble and addicted \\
\hline 3 & $\begin{array}{l}\text { Do your parents know you have } \\
\text { smoked? }\end{array}$ & Don't know until now & Do not know \\
\hline 4 & Is there a reason you smoke? & $\begin{array}{l}\text { The reason I smoke is that I see } \\
\text { my friend smoking }\end{array}$ & $\begin{array}{l}\text { Because of the influence of } \\
\text { friends }\end{array}$ \\
\hline 5 & $\begin{array}{l}\text { And tell me how did you get to } \\
\text { smoke? }\end{array}$ & $\begin{array}{l}\text { At first, I just tried 1 stick and my } \\
\text { cough didn't continue then I tried } \\
\text { again and so on I was addicted } \\
\text { until now }\end{array}$ & $\begin{array}{l}\text { Just trying to start with 1 stick and } \\
\text { continue }\end{array}$ \\
\hline 6 & $\begin{array}{l}\text { At what age did you first } \\
\text { smoke? }\end{array}$ & $\begin{array}{l}\text { 16 years } \\
\text { smow many cigarettes a day }\end{array}$ & Half Pack \\
\hline 7 & $\begin{array}{l}\text { Do you feel like quitting } \\
\text { smoking? }\end{array}$ & $\begin{array}{l}\text { There is a feeling of wanting to } \\
\text { stop but it's hard to get addicted }\end{array}$ & $\begin{array}{l}\text { There is a feeling of wanting to } \\
\text { stop }\end{array}$ \\
\hline 9 & $\begin{array}{l}\text { Do you feel restless if you don't } \\
\text { smoke? Or dizzy? }\end{array}$ & $\begin{array}{l}\text { Restless and feeling dizzy if you } \\
\text { don't smoke }\end{array}$ & Active smoker \\
\hline 10 & $\begin{array}{l}\text { What kind of cigarettes do you } \\
\text { smoke }\end{array}$ & Warehouse Salt Filter & Warehouse Salt Filter \\
\hline & & & Cigarette Pack \\
\hline
\end{tabular}

Table 4. Fast Food Interview Matrix in Youth from Informant 4

Name: Indra Kusuma

Age/TTL: 17 years (2 high schools)

Place of Interview: Restaurant

Interview Time : June 3, 2021 
E-ISSN: 2808-5361 http://e-journal.fkmumj.ac.id/
Proceeding The First Muhammadiyah InternasionalPublic Health and Medicine

Conference

\begin{tabular}{|c|c|c|c|}
\hline & QUESTION & INFORMATION ANSWER & ANSWER CONCLUSION \\
\hline 1 & $\begin{array}{l}\text { Please tell me how long have } \\
\text { you been smoking? }\end{array}$ & $\begin{array}{l}4 \text { years from the start of middle } \\
\text { school }\end{array}$ & Under 17 years old \\
\hline 2 & $\begin{array}{l}\text { How did you first taste } \\
\text { cigarettes? }\end{array}$ & $\begin{array}{l}\text { When you start smoking, you } \\
\text { immediately cough, there's just a } \\
\text { feeling of addiction }\end{array}$ & Cough and addiction \\
\hline 3 & $\begin{array}{l}\text { Do your parents know you have } \\
\text { smoked? }\end{array}$ & Of course not & Do not know \\
\hline 4 & Is there a reason you smoke? & $\begin{array}{l}\text { At first, I just tried to keep getting } \\
\text { addicted }\end{array}$ & Curious \\
\hline 5 & $\begin{array}{l}\text { And tell me how did you get to } \\
\text { smoke? }\end{array}$ & $\begin{array}{l}\text { Because the association follows } \\
\text { friends on smoking }\end{array}$ & Friends influence \\
\hline 6 & $\begin{array}{l}\text { At what age did you first } \\
\text { smoke? }\end{array}$ & 15 years & 15 years \\
\hline 7 & $\begin{array}{l}\text { How many cigarettes a day } \\
\text { smoke }\end{array}$ & About 3-8 sticks per day & 3-8 sticks per day \\
\hline 8 & $\begin{array}{l}\text { Do you feel like quitting } \\
\text { smoking? }\end{array}$ & $\begin{array}{l}\text { So far there is no desire to quit } \\
\text { smoking }\end{array}$ & Nothing \\
\hline 9 & $\begin{array}{l}\text { Do you feel restless if you don't } \\
\text { smoke? Or dizzy? }\end{array}$ & No, just lacking confidence & Lack of confidence \\
\hline 10 & $\begin{array}{l}\text { What kind of cigarettes do you } \\
\text { smoke }\end{array}$ & Magnum Blue & Magnum Blue \\
\hline
\end{tabular}

Knowledge can influence a person's behavior, including knowledge about the dangers of smoking that can affect smoking behavior. Adolescent knowledge relates to the existence of information facilities, such as libraries in schools, computer laboratories, and multimedia rooms to find the latest information. Knowledge about the dangers of smoking can lead to the development and growth of adolescents.

The majority of teenagers get influence by their peers to smoke. In this study, based on the FGDs conducted, peer invitation was one of the factors that influenced adolescents to smoke.

The number of cigarettes consumed by adolescents in this study can be seen, namely, 3 medium smokers spend 6-10 cigarettes per day and there is 1 heavy smoker teenager who can spend 11-15 cigarettes per day.

It can be seen that the critical period or prone to smoking behavior in junior high school or including the early adolescent development stage. Where early adolescence is the most critical period of peer influence, in this study, 3 teenagers wanted to stop consuming cigarettes but it was very difficult to do because these teenagers were addicted to cigarettes and there was 1 teenager who did not have the desire to stop consuming cigarettes. 
E-ISSN: 2808-5361 http://e-journal.fkmumj.ac.id/
Proceeding The First Muhammadiyah InternasionalPublic Health and Medicine

Conference

Cigarette type which can be purchased retail or per stick makes it easier for teenagers to buy and consume cigarettes because the price is very cheap when buying retail cigarettes or sticks so that teenagers tend to be tempted and feel addicted to cigarettes.

The junior high school period is a critical period of adolescence or is prone to smoking behavior or includes the early stages of adolescent development. Where early adolescence is the most critical period of peer influence, in this period they are looking for identity so that adolescents who experience a crisis of psychosocial aspects will follow their friends to be accepted in their group and recognized by their group.

Low prices can lead to the habit of consuming cigarettes in adolescents. In addition, several types of cigarettes are sold per stick or retail which also increases the desire of teenagers to buy these cigarettes. The types of retail cigarettes or cigarettes offered to make teenagers more interested in consuming cigarettes.

\section{CONCLUSIONS AND SUGGESTIONS}

Smoking can harm the body because cigarettes contain approximately 4000 chemicals, tar, carbon monoxide, and hydrogen cyanide. The number of adolescents who consume cigarettes is caused by several factors including knowledge, peer influence, low prices, desire to quit smoking, types of cigarettes, and education. Cigarettes contain various toxic chemicals that cause various physical disorders such as impotence, cancer, heart problems, and respiratory disorders such as shortness of breath, chronic obstructive pulmonary disease such as bronchitis and emphysema, and pregnancy disorders in women.

\section{REFERENCES}

Astuti, K. (2012) 'Description of Smoking Behavior in Adolescents in Bantul Regency', Insight, 10(1), pp. 77-87. Available at: http://fpsi.mercubuana-yogya.ac.id/wpcontent/uploads/2012/06/6.GAMBARAN-BEHAVIOR-MEROKOK-PADA-REMAJA-DIKABUPATEN-BANTUL.pdf.

Damang, SA, Syakur, R. and Andriani, R. (2019) 'Factors Associated with Smoking Behavior in Adolescents at SMP Negeri 7 Langgudu, Bima Regency', Journal of Community Health, 1(1), pp. 32-39. doi:10.36090/jkkm.v1i1.294.

Hanifah, S. and Hamdan, SR (2020) 'Overview of Smoking Behavior in Students in Bandung City', Proceedings of Psychology, 6(2), pp. 700-703.

Komasari, D. and Helmi, AF (2011) 'Factors Causing Smoking in Adolescents', Journal of Psychology, 27(1), pp. 37-47.

Rahmah, N. (2015) 'The Effect of Cigarettes on Health and the Formation of Human Character', Proceedings of the National Seminar, 01(1), p. 78. 